\title{
INSTITUTO VENEZOLANO DE INVESTIGACIONES CIENTIFICAS NATURAL RADIOCARBON MEASUREMENTS $V$
}

\author{
M. A. TAMERS
}

\author{
Instituto Venezolano de Investigaciones Científicas \\ Department of Chemistry, Caracas, Venezuela
}

The laboratory has been operating more than five years, supported entirely from Venezuelan government funds. Approximately 530 samples have been dated to the end of 1969. Of these, $40 \%$ are archaeologic specimens, the majority (141 samples) from Venezuela. Materials from most other countries of Latin America have been processed. The rest of the samples are from research programs of the Radiocarbon Laboratory itself. Thirty per cent of the total are measurements on carbonate species extracted from Venezuelan ground water aquifers.

In years previous to the inauguration of the Caracas laboratory (November, 1963), only 56 samples from Venezuela had been accepted by foreign universities (Rouse and Cruxent, 1963). Establishment of a radiocarbon dating facility permits scientists in this country to eliminate dependence on distant laboratories in the United States or Europe. Furthermore, possibilities for studies have expanded considerably and important cultural, scientific, and practical advances have been made. The pre-history of the entire Caribbean area is now being investigated (Cruxent and Rouse, 1969), as well as details in the Venezuelan chronology (Wagner, 1967; Zucchi, 1965). Ground waters of the arid zones of this country have been thoroughly sampled and critical facts have emerged (Tamers, 1967b). For example, it was found that the unique fresh water supply for the second largest city in Venezuela comes from a fossil ground water deposit that could be exhausted in the near future. A variety of other projects are yielding significant results, published periodically in international scientific journals.

The dates presented here, as in the previous lists, were calculated using 5568 years as the half-life of carbon-14. A.D. 1950 is the reference year in the B.P. (before present) notation of ages. The modern standard is taken as $95 \%$ of the activity of the NBS oxalic acid. Errors are the standard deviations arising from the random nature of the radioactive disintegration process. The modern reference activity is $21.7 \mathrm{cpm}$ and the background $6.9 \mathrm{cpm}$ for the $3 \mathrm{cc}$ benzene counter vessel used for the routine measurements. The laboratory employs liquid scintillation techniques with synthesized benzene. A chromium activated silicaalumina catalyst (Pietig and Scharpenseel, 1966) converts acetylene to benzene. Acetylene production is described in a previous date list (Tamers, 1969a).

\section{ACKNOWLEDGMENTS}

Continued close collaboration with the I.V.I.C. Dept. of Anthropology, J. M. Cruxent, head, and support from the Dept. of Chemistry, 
G. Chuchani, head, are important to the operation of the laboratory. Routine chemical analyses and the benzene syntheses are done by the technicians, V. García and F. Machado. A. Russo maintains the electronics.

Special acknowledgment must be made to the past director of I.V.I.C., Marcel Roche, who was responsible for the decision to establish the radiocarbon laboratory in 1963 and who has continued to be exceptionally interested in all ways with its functioning.

\section{SAMPLE DESCRIPTIONS}

\section{GROUND WATER SAMPLES}

Measurements presented here, except for IVIC-565, represent the continuation of the sequential sampling program for various ground water aquifers in Venezuela. The waters on the $\mathrm{N}$ and $\mathrm{S}$ sides of Lake Valencia and those of the Bosque Macuto in Barquisimeto are modern. When corrected for limestone dilution, they show nuclear weapon testing contamination (Tamers, 1967b). Annual samplings permit comparisons with previously measured excess activity levels of plants in this country, which, in favorable cases, can result in exact age determinations of these contemporary materials (Tamers, 1969b).

The Maracaibo aquifer is a non-recharged deposit and annual measurements verify this. Nevertheless, the well at La Cañada shows periodically decreasing ages, either due to infiltration of younger water from the inland Campo 4 deposit or from the Lake of Maracaibo, which is ca. $100 \mathrm{~m}$ distant.

The well at the Finca del Portugués was tested because it was believed that this ground water could not be more than a few years old. The radiocarbon contamination level in Venezuela being approx. constant at $160 \%$ modern during the past $5 \mathrm{yr}$ (cf. Sec. IV), if the limestone corrected concentration gave approx. this value, this would be evidence for the validity of radiocarbon dates on ground water. The following formula was used (Tamers, 1969b):

$$
\delta \mathrm{C}^{14}{ }_{\text {corrected }}=\frac{\delta \mathrm{C}^{14}{ }_{\text {final }}}{\delta \mathrm{C}^{14}{ }_{\text {initial }}} \div \frac{\left[\mathrm{C}_{\text {total }}\right]-1 / 2\left[\mathrm{HCO}_{3}-\right]}{\left[\mathrm{C}_{\text {total }}\right]}
$$

where $\left[\mathrm{HCO}_{3}{ }^{-}\right]$is the bicarbonate concentration $(=2.1 \mathrm{meq} / 1$ here $)$ measured at the well by a sulfuric acid titration controlled with a $\mathrm{pH}$ meter. $\left[\mathrm{C}_{\text {total }}\right]$ is the total amount of dissolved carbonate species $(=2.4$ $\mathrm{meq} / 1$ here). $\delta \mathrm{C}^{14}{ }_{\text {inal }}$ is the measured activity and $\delta \mathrm{C}^{14}{ }_{\text {initial }}$ is the activity of the modern standard. The value for $\delta \mathrm{C}^{14}{ }_{\text {corrected }}$ is calculated to be $156.4 \pm 7.9 \%$ modern, the error term taking into account uncertainties in carbonate species analyses. This agrees with the expected value.

Radiocarbon contents are reported as $\%$ of modern without correction for limestone dilution. Earlier measurements in these series are given in previous date lists. 
Wells of Valencia Lake Basin

IVIC-567. Mariara I

$\left(10^{\circ} 15^{\prime} \mathrm{N}\right.$ Lat, $67^{\circ} 43^{\prime} \mathrm{W}$ Long)

Collection

$\mathrm{C}^{14}$

(day/month/yr) (\% of modern)

IVIC-568. Mariara 2

$\left(10^{\circ} 13^{\prime} \mathrm{N}\right.$ Lat, $67^{\circ} 43^{\prime} \mathrm{W}$ Long)

IVIC-569. El Trompillo

$\left(10^{\circ} 4^{\prime} \mathrm{N}\right.$ Lat, $67^{\circ} 46^{\prime} \mathrm{W}$ Long)

IVIC-570. Güigüe 1

$\left(10^{\circ} 5^{\prime} \mathrm{N}\right.$ Lat, $67^{\circ} 47^{\prime} \mathrm{W}$ Long)

IVIC-571. Güigüie 2

$\left(10^{\circ} 5^{\prime} \mathrm{N}\right.$ Lat, $67^{\circ} 47^{\prime} \mathrm{W}$ Long)

IVIC-572. Güigüe 3

$\left(10^{\circ} 5^{\prime} \mathrm{N}\right.$ Lat, $67^{\circ} 47^{\prime} \mathrm{W}$ Long)

$4 / 2 / 69$

$88.9 \pm 0.7$

$4 / 2 / 69$

$99.0 \pm 0.8$

$4 / 2 / 69$

$100.2 \pm 0.7$

$4 / 2 / 69$

$97.8 \pm 0.8$

$4 / 2 / 69$

$93.9 \pm 0.8$

$4 / 2 / 69$

$96.5 \pm 0.8$

Barquisimeto Wells

IVIC-610. Macuto 1

$\left(10^{\circ} 3^{\prime} \mathrm{N}\right.$ Lat, $69^{\circ} 19^{\prime} \mathrm{W}$ Long $)$

IVIC-611. Macuto 2

( $10^{\circ} 3^{\prime} \mathrm{N}$ Lat, $69^{\circ} 19^{\prime} \mathrm{W}$ Long)

IVIC-612. Macuto 3

$\left(10^{\circ} 3^{\prime} \mathrm{N}\right.$ Lat, $69^{\circ} 19^{\prime} \mathrm{W}$ Long)

IVIC-613. Macuto 4

$\left(10^{\circ} 3^{\prime} \mathrm{N}\right.$ Lat, $69^{\circ} 19^{\prime} \mathrm{W}$ Long)

IVIC-614. Macuto 5

$\left(10^{\circ} 3^{\prime} \mathrm{N}\right.$ Lat, $69^{\circ} 19^{\prime} \mathrm{W}$ Long)

IVIC-615. Macuto 6

$\left(10^{\circ} 3^{\prime} \mathrm{N}\right.$ Lat, $69^{\circ} 19^{\prime} \mathrm{W}$ Long)

IVIC-616. Macuto 7

$\left(10^{\circ} 3^{\prime} \mathrm{N}\right.$ Lat, $69^{\circ} 19^{\prime} \mathrm{W}$ Long)

IVIC-617. Macuto 8

$\left(10^{\circ} 3^{\prime} \mathrm{N}\right.$ Lat, $69^{\circ} 19^{\prime} \mathrm{W}$ Long)

Maracaibo Aquifer Wells

IVIC-628. Campo 1, Pozo 28

$\left(10^{\circ} 33^{\prime} \mathrm{N}\right.$ Lat, $71^{\circ} 42.5^{\prime} \mathrm{W}$ Long)

IVIC-629. Campo 1, Pozo 23

(10 $32^{\prime} \mathrm{N}$ Lat, $71^{\circ} 43^{\prime} \mathrm{W}$ Long)

\begin{tabular}{ll}
$6 / 5 / 69$ & $93.0 \pm 0.8$ \\
$6 / 5 / 69$ & $89.1 \pm 0.8$ \\
$6 / 5 / 69$ & $82.4 \pm 0.8$ \\
$6 / 5 / 69$ & $98.8 \pm 0.9$ \\
$6 / 5 / 69$ & $86.5 \pm 0.8$ \\
$6 / 5 / 69$ & $85.6 \pm 0.7$ \\
$6 / 5 / 69$ & $87.9 \pm 0.8$ \\
$6 / 5 / 69$ & $83.9 \pm 0.8$ \\
& \\
\hline $2 / 9 / 69$ & $19.0 \pm 0.4$ \\
$2 / 9 / 69$ & $17.8 \pm 0.4$
\end{tabular}


IVIC-630. Campo 2, Pozo 6

Collection (day/month/yr)

$2 / 9 / 69$

$2 / 9 / 69$

$2 / 9 / 69$

$2 / 9 / 69$

(\% of modern)

$\left(10^{\circ} 30^{\prime} \mathrm{N}\right.$ Lat, $71^{\circ} 48^{\prime} \mathrm{W}$ Long)

IVIC-631. Campo 2, Pozo 2

$\left(10^{\circ} 30^{\prime} \mathrm{N}\right.$ Lat, $71^{\circ} 48^{\prime} \mathrm{W}$ Long)

IVIC-632. Campo 3A, Pozo 1

$\left(10^{\circ} 30^{\prime} \mathrm{N}\right.$ Lat, $71^{\circ} 43^{\prime} \mathrm{W}$ Long)

IVIC-633. La Cañada

$\left(10^{\circ} 25^{\prime} \mathrm{N}\right.$ Lat, $71^{\circ} 41^{\prime} \mathrm{W}$ Long)

Altos de Pipe

IVIC-565. Finca del Portugués

(10 $23^{\prime} \mathrm{N}$ Lat, $66^{\circ} 58^{\prime} \mathrm{W}$ Long)

II. ARCHAEOLOGIC SAMPLES

A. Venezuela

Indo-Hispanic Epoch
$\mathrm{C}^{14}$

$26.1 \pm 0.4$

$25.8 \pm 0.4$

$17.0 \pm 0.4$

$5.49 \pm 0.34$

$87.9 \pm 0.7$

IVIC-625. La Maternidad Norte

A.D. 1750

$200 \pm 60$

Small charcoal sample from surface exposed by moving sand dunes, $\mathrm{N}$ of Monumento de la Maternidad, Parque de Exposiciones, Coro, state of Falcón (11 $26^{\prime} \mathrm{N}$ Lat, $69^{\circ} 40^{\prime} \mathrm{W}$ Long). Assoc. pottery might be Dabajuroid from Caquetio Indians. Coll. 1969 and subm. by J. Cruxent, I.V.I.C. Comment: see IVIC-626.

IVIC-626. La Maternidad Sur

$500 \pm 60$

Charcoal from surface of same site as IVIC-625, but a little more S. Coll. at same time. Comment (J.C.): both IVIC-625 and IVIC-626 dates are reasonable; however, even after returning to site again, we were unable to find any trace of European artifacts.

\section{Neo-Indian Epoch}

\section{IVIC-673. El Muro de Yaima}

A.D. 1090

$860 \pm 70$

Charcoal taken 0.00 to $0.25 \mathrm{~m}$ below surface of shell mound NE of village of Santa Rita, Paraguaná peninsula, state of Falcón $\left(12^{\circ} 9^{\prime}\right.$ $\mathrm{N}$ Lat, $69^{\circ} 57^{\prime} \mathrm{W}$ Long). Assoc. with pottery of Dabajuroid style from Paraguaná which have not been dated. Coll. 1969 and subm. by J. Cruxent. Comment (J.C.): date is reasonable. Sample was expected to be Period IV.

\section{IVIC-574. Monou-teri}

$500 \pm 170$

Charcoal, 0.25 to $0.50 \mathrm{~m}$ below surface, near Mavaco R., a tributary of the Orinoco, Amazonas Terr. ( $3^{\circ} 25^{\prime} \mathrm{N}$ Lat, $65^{\circ} 30^{\prime} \mathrm{W}$ Long). Assoc. 
with crude simple pottery. First date for region and indicates origins of Yanamamo (Waika) Indians now in area. Coll. 1969 and subm. by E. Wagner, I.V.I.C., who estimated age at 400 to 1000 yr. Comment (E.W.): date is reasonable.

IVIC-573. Monou-teri soil, 0.00 to $0.25 \mathrm{~m}$

$$
1010 \pm 70
$$

Black earth from same pit as IVIC-574, taken 0.00 to $0.25 \mathrm{~m}$ below surface. Abundant rootlets removed by hand and carbonates removed by acid pretreatment. Organic carbon content was $1.8 \%$, relatively high. Coll. at same time as IVIC-574. Sample used as part of program to study the validity of radiocarbon dates on soil. Comment: see IVIC-575.

\section{IVIC-575. Monou-teri soil, 0.25 to $0.50 \mathrm{~m}$}

$$
910 \pm 70
$$

Black earth in contact with charcoal of IVIC-574, 0.25 to $0.50 \mathrm{~m}$ below surface. Rootlets removed by hand and absence of carbonates insured by acid pretreatment. Organic carbon content was $1.6 \%$, a high value similar to that of the adjacent level of IVIC-573. Coll. at same time as previous samples. Control for investigation of validity of radiocarbon dates on soil. Comment: IVIC-573 and IVIC-575, with statistically indistinguishable ages, produce radiocarbon dates older than that of assoc. charcoal. This is surprising in view of conclusions of the Bonn lab. (Scharpenseel and Pietig, 1969) that soil-date errors make these materials appear too young. We also found, in the Taima-taima site, a wood sample (IVIC-655, this date list) that was younger than organic carbon fraction of its assoc. soil (IVIC-627, this date list). An explanation of the Monou-teri soil samples is that the soil was mixed deeper than $0.50 \mathrm{~m}$ before IVIC-574 was deposited. However, this could not have been the case for Taima-taima samples.

\section{IVIC-645. EI Mocao Alto bones A-1}

$650 \pm 80$

Organic carbon of human bone, not charred, taken 0.75 to $1.10 \mathrm{~m}$ below surface, Trench A, Pit 1, $4 \mathrm{~km}$ SE Mucuchíes, state of Mericia, in Venezuelan Andes ( $9^{\circ} 19^{\prime} \mathrm{N}$ Lat, $71^{\circ} 8^{\prime} \mathrm{W}$ Long). Assoc. with ceramic fragments, stone slabs, grinding stones, and lithic bat wing pendants. El Mocao Alto charcoal previously dated from 450 to 1120 B.P. (Tamers, 1969a). Coll. 1968 and subm. by E. Wagner. Hydrochloric acid pretreatment completely removed carbonates. Organic carbon content was $3.0 \%$. Comment (E.W.): date falls within range of charcoal dates, but is older than IVIC-481 which dated human bones at $230 \pm 40$ (Radiocarbon, 1969, v. 11, p. 404). Human skeleton material is atypical if it is Indian.

IVIC-650. La Era Nueva E-8, 0.25 to $0.50 \mathrm{~m}$

$970 \pm 70$

Charcoal from Pit 8 , Sec. E. excavated 0.25 to $0.50 \mathrm{~m}$ below surface of site ca. $8 \mathrm{~km}$ SE Mucuchíes, state of Mérida, in Venezuelan Andes $\left(9^{\circ} 19^{\prime} \mathrm{N}\right.$ Lat, $71^{\circ} 10^{\prime} \mathrm{W}$ Long). Previous dates for site were 820 to 
1060 B.P. (Tamers, 1969a). Assoc. with crude pottery, bones, terrestrial snail shells, and corn cobs. Coll. 1968 and subm. by E. Wagner. Comment (E.W.): agrees with previous dates from same site.

IVIC-651. La Era Nueva E-9, 0.50 to $0.75 \mathrm{~m}$

Modern

Small charcoal sample from Pit 9 , Sec. E, taken 0.50 to $0.75 \mathrm{~m}$ below surface of same site as IVIC-650. Pit and section, at level 0.25 to $0.50 \mathrm{~m}$ below surface, previously dated at $820 \pm 70$ B.P. (IVIC-447, Radiocarbon, 1969, v. 11, p. 404). Coll. 1968 and subm. by E. Wagner. Comment (E.W.): probably contaminated with modern charcoal.

\section{IVIC-648. Frailejón leaves}

A.D. 1520

$$
430 \pm 80
$$

Dried frailejón (Espeletia sp.) leaves apparently used as packing material for artifacts including ceramic fragments, bat wing pendants, and fruit seeds found in cave near Mucuchíes, state of Mérida, Venezuelan Andes by P. Villarreal. Coll. 1967 and subm. by E. Wagner. Comment (E.W.): date reasonable for this area.

\section{La Calzada series}

Continuation of samples dated from artificial mound, No. 1, near La Calzada ranch in state of Barinas $\left(8^{\circ} 2^{\prime} \mathrm{N}\right.$ Lat, $70^{\circ} 8^{\prime} \mathrm{W}$ Long). Series of dates ranging from modern to 1990 B.P. were reported in previous date list (Tamers, 1969a). Mound contains Caño del Oso and La Betania complex ceramic from Neo-Indian Periods II to IV (Zucchi, 1965). Coll. 1968 to 1969 by A. Zucchi and E. Duran, I.V.I.C., and subm. by A. Zucchi. The samples reported here are all charcoal.

\section{IVIC-549. La Calzada B-2, 9.25 to $9.50 \mathrm{~m}$}

Sample from Trench B, Pit 2. Subm. to obtain date on lower level of mound. Caño del Oso complex pottery found in all levels of this trench and pit. Level 8.50 to $8.75 \mathrm{~m}$ previously dated at $1510 \pm 70$ B.P. (IVIC471, Radiocarbon, 1969, v. 11, p. 405).

IVIC-550. La Calzada B-1, 9.25 to $9.50 \mathrm{~m}$

$$
1490 \pm 80
$$

\section{IVIC-551. La Calzada B-1, 9.50 to $9.75 \mathrm{~m}$}

Samples from Trench B, Pit 1. Level 7.75 to $8.00 \mathrm{~m}$ previously dated at $1800 \pm 100$ в.P. (IVIC-472, Radiocarbon, 1969, v. 11, p. 405).

IVIC-580. La Calzada B-3, 11.75 to $12.00 \mathrm{~m}$

IVIC-581. La Calzada B-3, 12.00 to $12.25 \mathrm{~m}$

IVIC-582. La Calzada B-3, 12.25 to $12.50 \mathrm{~m}$

\footnotetext{
$1690 \pm 90$ A.D. 260

$1740 \pm 70$

A.D. 210

$1400 \pm 60$

A.D. 550
} 
IVIC-583. La Calzada B-3, 12.50 to $12.75 \mathrm{~m}$

IVIC-584. La Calzada B-3, 12.75 to $13.00 \mathrm{~m}$

Samples from Trench B, Pit 3. Assoc. with material corresponding to Caño del Oso complex.

IVIC-586. La Calzada A-8, 10.50 to $10.75 \mathrm{~m}$

IVIC-587. La Calzada A-8, 11.50 to $11.75 \mathrm{~m}$

IVIC-588. La Calzada A-8, 12.00 to $12.25 \mathrm{~m}$

Samples from Trench A, Pit 8. Assoc. with Caño del Oso complex ceramics.

IVIC-593. La Calzada A-6, 9.75 to $10.00 \mathrm{~m}$

IVIC-592. La Calzada A-6, 11.75 to $12.00 \mathrm{~m}$

IVIC-591. La Calzada A-6, 12.50 to $12.75 \mathrm{~m}$

Samples from Trench A, Pit 6. All with Caño del Oso complex ceramics.

IVIC-590. La Calzada A-14, 12.00 to 12.25 m A.D. 220

$1730 \pm 80$

Sample from Trench A, Pit 14. In contact with Caño del Oso and La Betania complex ceramics.

General Comment (A.Z.): series of dates obtained for Mound 1 presents irregularity that can be explained by the fact that the constructors employed earth corresponding to old habitation surfaces. Dates from 1500 to 2870 B.P. are from these old occupations, whereas those from 1400 to 1500 B.P. are possibly from initiation of mound construction.

\section{IVIC-557. Puerto Carayaca 1}

$$
1050 \pm 70
$$

Charcoal sample, PC 1-pp 1-6, from Pit $1,0.75$ to $0.90 \mathrm{~m}$ below surface in excavation on $\mathrm{W}$ side of Puerto Carayaca village, near La Guaira, Venezuela $\left(10^{\circ} 30^{\prime} \mathrm{N}\right.$ Lat, $67^{\circ} 15^{\prime} \mathrm{W}$ Long). Assoc. with direct secondary human burial, abundant ceramic fragments, fish bones, sea shells, and a polished stone. Coll. 1968 and subm. by J. Armand, Univ. de Oriente, Ciudad Bolivar, Venezuela.

\section{IVIC-589. Quíbor 2nd}

$1650 \pm 70$

Charcoal from Indian burial site in Bolivar Plaza of Quíbor, state of Lara, Venezuela $\left(9^{\circ} 55^{\prime} \mathrm{N}\right.$ Lat, $69^{\circ} 38^{\prime} \mathrm{W}$ Long). Taken ca. $1.20 \mathrm{~m}$ below 
surface and assoc. with unclassified type of pottery, but believed to be at least $1000 \mathrm{yr}$ old. Previous charcoal date on this site of $290 \pm 60$ B.P. (IVIC-332, Radiocarbon, 1967, v. 9, p. 241) was unacceptable and considered an intrusive sample. Coll. 1969 by A. Lucena, Univ. Central de Venezuela, Caracas; subm. by J. Cruxent. Comment (J.C.): radiocarbon date agrees with estimated antiquity.

\section{Paleo-Indian Epoch}

\section{IVIC-627. Taima-taima soil}

$12,580 \pm 150$

10,630 в.c.

Friable, blocky structure, sandy soil, dark gray, with abundant sulphur, taken 1.50 to $2.25 \mathrm{~m}$ below surface of Pleistocene animal kill site near Coro, state of Falcón, Venezuela ( $11^{\circ} 30^{\prime} \mathrm{N}$ Lat, $69^{\circ} 30^{\prime} \mathrm{W}$ Long). Date on organic carbon, $0.2 \%$ concentration, carbonate removed by acid pretreatment. Sample from soil Horizon $\mathrm{C}$ and in contact with animal bones. Organic carbon in other bones from this site previously dated at $13,010 \pm 280$ and 14,440 \pm 435 в.P. (IVIC-191-1 and IVIC-191-2, Radiocarbon, 1966, v. 8, p. 206-207). Coll. 1969 and subm. by J. Cruxent. Comment: Bonn lab. showed (Scharpenseel and Pietig, 1969) that soil dates can be too young by as much as $5000 \mathrm{yr}$ in regions with abundant plant cover. However, the situation here is confused because the present vegetation is scarce, but A horizon has very high carbon content. Soil dating in this site is being continued.

\section{IVIC-655. Taima-taima wood}

$11,860 \pm 130$ 9910 B.c.

Wood, black with abnormally high density, apparently well-preserved, from same site and ca. same depth as sample of IVIC-627. Carbonates removed by acid pretreatment. Sample taken in apparent direct assoc. with Pleistocene animal bones. Coll. 1969 and subm. by J. Cruxent. Taima-taima archaeologic site has been described in a previous article (Cruxent, 1967). Comment: wood was preserved by sulfides in soil. Concordance of this date with that of soil sample, IVIC-627, was unexpected. Even more difficult to explain is fact that bone dates are older, since bone invariably has errors that make dates too recent or else has no error. One possible explanation is that wood sample is intrusive, buried by animals that came after those offering bones for previous dating.

\section{B. Colombia}

\section{IVIC-559. Necropolos Alto}

Small charcoal sample, S-Gua-2, T-1, MC-1, from filling of Tomb 1, $1.5 \mathrm{~m}$ below surface. Municipality of Guapotá, Dept. of Santander, Colombia $\left(6^{\circ} 18^{\prime} \mathrm{N}\right.$ Lat, $73^{\circ} 19^{\prime} \mathrm{W}$ Long). Assoc. with ceramic vessels similar to those found in nearby Oiba, Santander. Tomb is a well with lateral chamber. Coll. 1966 and subm. by D. R. Sutherland, Dept. Anthropol. and Sociol., Univ. S. Carolina, U.S.A. Comment (D.R.S.): this 
sample and IVIC-560 are 1st radiocarbon dates for area $\mathrm{N}$ of Bogota in Santander. Age is reasonable.

\section{IVIC-560. San Lorenzo}

$790 \pm 60$

Charcoal sample, S-Oib-1, T-3, MC-1, found inside ceramic vessel on floor of Tomb 3, $1.9 \mathrm{~m}$ below surface. On San Lorenzo farm, Municipality of Oiba, Dept. Santander, Colombia (6 $6^{\circ} 13^{\prime} \mathrm{N}$ Lat, $73^{\circ} 15^{\prime} \mathrm{W}$ Long). Assoc. with 6 ceramic vessels, a ceramic whistle, and human bones, on floor of tomb with lateral chamber. Artifacts similar to those of IVIC559. Coll. 1967 and subm. by D. R. Sutherland. Comment (D.R.S.): date is reasonable.

\section{IVIC-596. Finca Moralba 18}

$710 \pm 60$

Charcoal sample, Moralba Tube 18, from Trench 2, lower part of Level 6, base of stratum with Sonso style sherds. From Moralba farm, W bank of Cauca R., $5 \mathrm{~km} \mathrm{~S}$ Mediacanoa, Dept. Valle, Colombia $\left(3^{\circ} 55^{\prime} \mathrm{N}\right.$ Lat, $76^{\circ} 20^{\prime} \mathrm{W}$ Long). This material should approx. date beginning of Sonso occupation at site. Upper interface of stratum, i.e., end of Sonso occupation, was dated previously at A.D. $1550 \pm 70$ (GrN-4697, Radiocarbon, 1967, v. 9, p. 152). Coll. 1964 and subm. by Warwick Bray, London Univ., England. Comment (W.B.): quite acceptable. Sample stratigraphically and chronologically older than GrN-4697 and these 2 dates bracket Sonso occupation at Moralba site. Allowing for standard deviations on both dates, duration of this occupation is rather longer than anticipated, but is, nevertheless, satisfactory. IVIC-596 fulfills another expectation. Previous dates for Sonso material in Cauca Valley were ca. mid-16th century A.D., whereas dates on similar material in Calima Valley were mid-13th century (IVIC-160, Radiocarbon, 1966, v. 8, p. 209 and NPL-60, Radiocarbon, 1964, v. 6, p. 29). IVIC-596 agrees well with Calima dates.

\section{IVIC-597. Finca Moralba 166}

$2840 \pm 270$

890 в.c.

Very small charcoal sample (large date error term), Cauca Label 166, from Moralba farm, W bank of Cauca R., $5 \mathrm{~km} \mathrm{~S}$ Mediacanos, Dept. Valle, Colombia ( $3^{\circ} 55^{\prime} \mathrm{N}$ Lat, $76^{\circ} 20^{\prime} \mathrm{W}$ Long). Obtained from Trench 2, lower part of Level 8, near base of Yotoco style stratum. Estimated date A.D. 1000 to A.D. 1400, and early stage of Yotoco occupation of site. Coll. 1964 and subm. by Warwick Bray. Comment (W.B.): surprisingly early date which conflicts with IVIC-598 and previous A.D. $1175 \pm 65$ (GrN-4694, Radiocarbon, 1967, v. 9, p. 151) for similar pottery from Yotoco Ferry excavation. Dates seem more reasonable and nothing suggests long duration for Yotoco phase. I would be inclined to discount IVIC-597, but have no explanation for discrepancy. 
IVIC-598. Yotoco Ferry 13

\section{A.D. 1100}

$850 \pm 140$

Small charcoal sample from Trench $1,1.4$ to $1.5 \mathrm{~m}$ below surface on E bank of Cauca R., opposite its confluence with Yotoco R. near town of Yotoco, Dept. Valle, Colombia ( $3^{\circ} 50^{\prime} \mathrm{N}$ Lat, $76^{\circ} 40^{\prime} \mathrm{W}$ Long). Assoc. with sherds of Yotoco style and should date a middle stage of Yotoco occupation of site. Sample is stratigraphically between others previously dated at A.D. $1175 \pm 65$ (GrN-4694, Radiocarbon, 1967, v. 9, p. 151) and A.D. $1780 \pm 40$ (GrN-4940, Radiocarbon, 1967, v. 9, p. 152). Coll. 1964 by E. Moseley, Harvard Univ., Massachusetts, U.S.A., and subm. by W. Bray. Comment (W.B.): as expected. IVIC-598 agrees closely with GrN-4694, which is stratigraphically a little earlier within same stratum.

\section{Trinidad}

\section{Palo Seco series}

\section{IVIC-638. Palo Seco D-4, 0.25 to $0.50 \mathrm{~m}$}

IVIC-639. Palo Seco D-4, 0.50 to $0.75 \mathrm{~m}$

IVIC-640. Palo Seco D-4, 0.75 to $1.00 \mathrm{~m}$

IVIC-641. Palo Seco D-4, 1.00 to $1.25 \mathrm{~m}$

$$
\begin{gathered}
2130 \pm 80 \\
180 \text { B.C. } \\
1480 \pm 70 \\
\text { A.D. } 470 \\
1990 \pm 70 \\
40 \text { B.C. } \\
2060 \pm 80 \\
110 \text { B.C. }
\end{gathered}
$$

Charcoal samples from a shell midden, No. 1, Trench D, Pit 4, on $S$ coast of Trinidad, in front of delta of the Venezuelan Orinoco R. Site in Trinidad Tesoro Beach Camp, Palo Seco municipality $\left(10^{\circ} 4^{\prime} \mathrm{N}\right.$ Lat, $61^{\circ} 35^{\prime} \mathrm{W}$ Long). Sample important for study of the entrance of Indians from continent to West Indies. Site described previously (Bullbrook, 1953). Expected to date in Period III of Rouse and Cruxent chronology (Rouse and Cruxent, 1963). Coll. 1969 and subm. by F. Olsen and I. Rouse, Yale Univ. and J. Cruxent, I.V.I.C. Comment (J.C.): IVIC-638 must be contaminated with asphalt, which was present on surface in this zone. Date should be disregarded. Other dates are reasonable.

\section{Cedros series}

\section{IVIC-642. Cedros A-1, 0.00 to $0.50 \mathrm{~m}$}

$$
\begin{array}{r}
2140 \pm 70 \\
190 \text { B.C. } \\
1850 \pm 80 \\
\text { A.D. } 100
\end{array}
$$

IVIC-643. Cedros A-1, 0.50 to $0.75 \mathrm{~m}$

Charcoal samples from a shell midden, Trench A, Pit 1, near end of Cedros peninsula, $\mathrm{N}$ of Envieuse Bay, Trinidad $\left(10^{\circ} 2^{\prime} \mathrm{N}\right.$ Lat, $61^{\circ} 57^{\prime} \mathrm{W}$ Long). Site could signal arrival of Saladoid people in Trinidad. Expected to date in Period II and be older than Palo Seco. Coll. 1969 and subm. by F. Olsen, I. Rouse, J. A. Correia, and J. Cruxent. Comment (J.C.): 
dates are reasonable; they are not statistically distinguishable and can be averaged to $1995 \pm 50$ в.P.

\section{ETHNOLOGIC SAMPLES}

The application of nuclear weapon contamination of the biosphere to the estimation of the possible ages of recent materials was described in a previous publication (Tamers, 1969b). At that time it appeared that there was a definite decrease in Venezuela for the years 1960 and 1961. However, two recent known-age samples (IVIC-539 and IVIC-541, this date list), have devaluated this conclusion and the dating is now most useful in the region 1963 to 1965 , when the large increase occurred.

The previous work with the Warao Indians of E Venezuela showed that they were calculating in the past with clearly less accuracy than peoples of more developed civilizations. But the samples were not collected by professional ethnologists and there remained the question whether the inexperience of the collectors could account for the errors in the Indians' age estimations. In this date list are presented samples taken under optimum conditions, by a professional who had been living with this group of primitive peoples for more than a year and who is familiar with their language and many of their customs. Samples described here come from the Piaroa Indians of the S Amazonas Terr. of Venezuela. The houses of this tribe are large conical structures with roofs made of various types of palm leaves. Samples coll. and subm. by J. Monod, Lab. d'Anthropol. Sociale, Collège de France, Paris.

\section{IVIC-533. Caño Naranjillo IA}

$152.5 \pm 1.0 \%$ modern

Mavaco palm leaves, with old appearance, taken from midway up roof, exterior, of communal house, Caño Naranjillo, Cuao R., a tributary of the Sipapo ( $5^{\circ} 5^{\prime} \mathrm{N}$ Lat, $67^{\circ} 35^{\prime} \mathrm{W}$ Long). This is the oldest house occupied by this group of Piaroa from the Lower Cuao. Indians estimated construction date as summer, 1964. Coll. Aug., 1968. Comment: see IVIC534 .

\section{IVIC-534. Caño Naranjillo $1 B$}

$148.7 \pm 1.0 \%$ modern

Clarera palm leaves from lower part of roof, exterior, of same structure as IVIC-533 and coll. at same time. Comment: radiocarbon dates agree well with Indians' calculations.

\section{IVIC-535. Caño Naranjillo 2A}

$143.0 \pm 1.0 \%$ modern

Mavaco palm leaves from abandoned communal house of same camp as IVIC-533 and IVIC-534. Coll. Aug., 1968 from midway up roof, exterior. Oldest structure still standing in region. Not occupied since 1964 when replaced by present communal house. Indians stated that it was only a provisional building and was constructed in winter, 1962. However, sample submitter doubted that Indians would have lived in this small house 2 yr before constructing present shelter. Comment: see IVIC536 . 
IVIC-536. Caño Naranjillo 2B

$161.3 \pm 1.0 \%$ modern

Llanera palm leaves from midway up roof of same structure as IVIC535, also exterior, opposite side. Coll. same time as IVIC-535. Comment: radiocarbon dates of this and previous sample would suggest late 1963 or early 1964 and do not agree with Indians' calculation of 1962. The 196364 date is more reasonable since it indicates that Indians did not stay long in this provisional structure.

IVIC-537. Caño Cucurito 3A

$126.2 \pm 0.9 \%$ modern

Llanera palm leaves from lower, exterior part of roof of abandoned house of "Carlo" and his group on Caño Cucurito, tributary of Cuoto R. (5 $5^{\circ} 0^{\prime} \mathrm{N}$ Lat, $67^{\circ} 35^{\prime} \mathrm{W}$ Long). Coll. Aug., 1968. Indians calculated construction in 1963. Comment: radiocarbon content does not disagree with Indians' estimation of age.

IVIC-601. Caño Raya 1

$141.3 \pm 0.9 \%$ modern

Temiche palm leaves with old appearance from lower part of roof of abandoned chiruatto type house on Caño Paria Chiquito, tributary of Orinoco R. ( $5^{\circ} 30^{\prime} \mathrm{N}$ Lat, $67^{\circ} 40^{\prime} \mathrm{W}$ Long). Indians stated that this house was constructed $1 \mathrm{yr}$ after that of IVIC-537 and that it was begun at end of 1963 and terminated June, 1964. Sample coll. Dec., 1968. Comment: radiocarbon content agrees exactly with Indians' late 1963, early 1964 calculation.

IVIC-602. Caño Raya 2A

$152.5 \pm 1.0 \%$ modern

Ura (?) palm leaves, old appearance, from wall of abandoned house of rectangular type with double roof. Same site as IVIC-601. This structure built in 2 steps, actually 2 houses connected. Sample from oldest part coll. Dec., 1968. This is oldest house constructed by Tsitino, but he calculated it as only $1 \mathrm{yr}$ old, i.e., 1967. Comment: radiocarbon content is a little low, but does not disagree completely with date estimation.

IVIC-603. Caño Raya 2B

$146.7 \pm 1.0 \%$ modern

Palm leaves from roof of structure of IVIC-602. Coll. at same time. Comment: this radiocarbon content is lower than any measured in Venezuela during 1965 to 1968. It might suggest that the house was built in 1964. More samples should be taken here.

IVIC-604. Caño Raya 4

$159.9 \pm 1.0 \%$ modern

Temiche palm leaves from lower part of roof of oval-shaped house inhabited by Riu. In same site as IVIC-601. Coll. Dec., 1968. Leaves of relatively young appearance. Indians stated construction date as beginning of 1968. Comment: radiocarbon content agrees with Indians' statement.

IVIC-605. Caño Raya 3A

$159.1 \pm 1.1 \%$ modern

Palm leaves from lower part of roof of house of Antonio Luis. Coll. Jan., 1969 in camp on tributary of Caño Paria Chiquito $\left(50^{\circ} 25^{\prime} \mathrm{N}\right.$ Lat, 
$67^{\circ} 35^{\prime} \mathrm{W}$ Long). In principle constructed at end of 1967. Comment: see IVIC-606.

IVIC-606. Caño Raya 3B

$156.5 \pm 1.0 \%$ modern

Palm leaves from opposite side of lower part of roof of structure of IVIC-605. Coll. same time. Comment: radiocarbon contents do not disagree with age estimation.

\section{IVIC-607. Caño Santan}

$155.2 \pm 1.0 \%$ modern

Temiche palm leaves, old appearance, from lower part of roof of communal house on Caño santan, tributary of Cataniapo R. $\left(5^{\circ} 45^{\prime} \mathrm{N}\right.$ Lat, $67^{\circ} 30^{\prime} \mathrm{W}$ Long). Oldest inhabited structure in Camp. Coll. Jan., 1969. Indians stated construction date as 1965 . Comment: radiocarbon content does not disagree with Indians' estimation of age.

\section{IVIC-608. Rabipelado}

$159.1 \pm 1.0 \%$ modern

Mavaco palm leaves, old appearance, from lower part of roof of small abandoned churuata house on Catariapo R., near Rabipelado R., a tributary of the Orinoco $\left(5^{\circ} 45^{\prime} \mathrm{N}\right.$ Lat, $67^{\circ} 30^{\prime} \mathrm{W}$ Long). Indians stated that structure was only ca. 1 yr old, i.e., built in 1967. However, sample collector doubts this because of very old appearance of house. Coll. Jan., 1969. Comment: radiocarbon content requires only that house was built after 1963 and does not contradict Indians' statement.

General Comment: this group of ethnologic samples represents 9 houses, but, unfortunately, majority date within the last years of almost constant radiocarbon contamination, i.e., 1965 to 1968. Radiocarbon contents of these materials do not disagree with Indians' calculations, but possible ages are too numerous to determine Indians' ability to count in the past. However, 4 houses, IVIC-533, 534, IVIC-535, 536, IVIC-537, and IVIC601 , were estimated as pre-1965 and provide a more significant group. Here, one calculation by the Indians is clearly wrong (IVIC-535, 536), 2 are certainly right (IVIC-533, 534 and IVIC-601), and 1 is possible (IVIC537). Also, age of house, IVIC-602, 603 probably is incorrect, but this is not as certain as that of IVIC-535, 536. Although these results by the ethnologist collector are better than those from the previous date list, Indians made at least one clear mistake which supports the previous suggestion that these primitive populations are not calculating past events with the accuracy of peoples in more developed civilizations.

\section{KNOWN AGE SAMPLES}

Periodic measurements of rarliocarbon contamination of atmospheric $\mathrm{CO}_{2}$ in Veneurifla continues. As vetore, plant materials are employed. Excess levels, alter reaching a rounded peak in 1965 (Tamers, 1969b), are slowly decreasing. Contributions from the recent tests on the Asian continent and in the Pacific Ocean have not been noticed, nor is there any seasonal tend *icy. 
Sample

no. Sample

Date

$\delta \mathrm{C}^{14}$

\begin{tabular}{lllll}
\hline IVIC-555 & Hojas de Guama & 29 Nov. 1968 & $158.9 \pm 1.3 \%$ modern \\
IVIC-558 & Hojas de Guama & 29 Dec. 1968 & $158.3 \pm 0.9 \%$ modern \\
IVIC-566 & Hojas de Guama & 29 Jan. 1969 & $154.0 \pm 0.9 \%$ modern \\
IVIC-594 & Hojas de Guama & 28 Feb. 1969 & $156.2 \pm 0.9 \%$ modern \\
IVIC-599 & Hojas de Guama & 28 Mar. 1969 & $154.7 \pm 1.0 \%$ modern \\
IVIC-609 & Hojas de Guama & 30 Apr. 1969 & $150.9 \pm 1.1 \%$ modern \\
IVIC-618 & Hojas de Guama & 16 May 1969 & $145.0 \pm 0.9 \%$ modern \\
IVIC-619 & Hojas de Guama & 30 May 1969 & $134.2 \pm 1.1 \%$ modern \\
IVIC-620 & Hojas de Guama & 30 June 1969 & $145.0 \pm 0.8 \%$ modern \\
IVIC-622 & Hojas de Guama & 31 July 1969 & $154.3 \pm 1.0 \%$ modern \\
IVIC-624 & Hojas de Guama & 29 Aug. 1969 & $154.8 \pm 1.1 \%$ modern \\
IVIC-646 & Hojas de Guama & 1 Oct. 1969 & $157.6 \pm 1.1 \%$ modern \\
IVIC-647 & Hojas de Guama & 15 Oct. 1969 & $152.8 \pm 1.0 \%$ modern \\
IVIC-656 & Hojas de Guama & 30 Oct. 1969 & $153.8 \pm 1.0 \%$ modern \\
IVIC-676 & Hojas de Guama & 28 Nov. 1969 & $155.9 \pm 1.0 \%$ modern
\end{tabular}

Green leaves from 2 Guama trees (Inga Fastuosa) in Altos de Pipe, $14 \mathrm{~km}$ from Caracas (10 $23^{\prime} \mathrm{N}$ Lat, $66^{\circ} 58^{\prime} \mathrm{W}$ Long). IVIC-555 came from same tree used previously for this purpose and rest of samples from a tree $10 \mathrm{~m}$ distant. Coll. and subm. by memberss of Radiocarbon Lab. of I.V.I.C. Comment: exceptionally low values noted for May and June, 1969 (IVIC-618, 619, 620).

\section{IVIC-539. Hojas de Maiz}

$120.8 \pm 1.4 \%$ modern

Green leaves from corn plant in Maracay, state of Aragua, Venezuela $\left(10^{\circ} 15^{\prime} \mathrm{N}\right.$ Lat, $67^{\circ} 35^{\prime} \mathrm{W}$ Long). Coll. Jan. 1960 by F. Herold, I.V.I.C., and subm. by members of the Radiocarbon Lab., I.V.I.C. This is a known age sample. Comment: see IVIC-541.

\section{IVIC-541. El Cenizo Alfalfa}

$117.7 \pm 1.3 \%$ modern

Green alfalfa plants growing in the region of El Cenizo, state of Trujillo, Venezuela $\left(9^{\circ} 30^{\prime} \mathrm{N}\right.$ Lat, $70^{\circ} 49^{\prime} \mathrm{W}$ Long). Coll. 1961 by F. Herold and subm. by members of the Radiocarbon Lab., I.V.I.C. This is a known age sample. Comment: both IVIC-539 and IVIC-541 have higher activities than previously seen in Venezuela for 1960 and 1961 (Tamers, 1969a). Decrease previously assumed for these years is not clear and cannot be used for age estimations of recent events here. 
IVIC-562. Venezuelan plants

$167.6 \pm 1.7 \%$ modern

Leaves and stems of small live plants growing in various localities in region of the llanos and coast of Venezuela. Coll. 1964 by K. Heinze, I.V.I.C. visitor in Lab. of F. Herold; subm. by members of the Radiocarbon Lab., I.V.I.C. This is a known age sample. Comment: agrees with previous measurement for this year in Venezuela.

$$
\text { v. GEOLOGIC SAMPLES }
$$

\section{Bahía EI Tablazo series}

This project dating underwater sediments continues that reported in date list IV; preliminary findings have been pub. (Tamers, 1969c). Samples are from top $20 \mathrm{~cm}$ of El Tablazo Bay or adjacent Gulf of Venezuela. Unless noted otherwise, carbonates were removed by hydrochloric acid wash. Coll. 1968 and subm. by members of Radiocarbon Lab., I.V.I.G.

\section{IVIC-542. Golfo de Venezuela C-20}

$$
400 \pm 70
$$

Fine sand with few shells in Gulf of Venezuela near San Carlos I. (11 ${ }^{\circ} 2^{\prime} \mathrm{N}$ Lat, $71^{\circ} 38^{\prime} \mathrm{W}$ Long).

IVIC-543 (c). Golfo de Venezuela C-21 carbonates 790 B.c.

Carbonate portion of sand with very little organic carbon $\left(11^{\circ} 3^{\prime}\right.$ $\mathrm{N}$ Lat, $71^{\circ} 40^{\prime} \mathrm{W}$ Long).

IVIC-544. Golfo de Venezuela C-22

A.D. 1110

Clayey mud with few shells in Gulf of Venezuela near San Carlos I. $\left(11^{\circ} 3^{\prime} \mathrm{N}\right.$ Lat, $71^{\circ} 37^{\prime} \mathrm{W}$ Long).

IVIC-544.(c). Golfo de Venezuela C-22 carbonates $2150 \pm 110$ B.c.

Carbonate portion of clayey-mud sample in Gulf of Venezuela $\left(11^{\circ}\right.$ $3^{\prime} \mathrm{N}$ Lat, $71^{\circ} 37^{\prime} \mathrm{W}$ Long). Organic portion also dated.

\section{IVIC-503(c). Lado del Canal C-7 carbonates}

$$
1860 \pm 70
$$

Carbonate portion of coarse sand with many shells and stones sample from $\mathrm{E}$ side of canal $\left(10^{\circ} 48^{\prime} \mathrm{N}\right.$ Lat, $71^{\circ} 36^{\prime} \mathrm{W}$ Long). Previous date on organic fraction was $4560 \pm 80$ B.P. (IVIC-503, Radiocarbon, 1969, v. 11, p. 420).

\section{IVIC-545. Golfo de Venezuela C-23}

Clayey mud with few shells in Gulf of Venezuela near San Carlos I. ( $11^{\circ} 1^{\prime} \mathrm{N}$ Lat, $71^{\circ} 37^{\prime} \mathrm{W}$ Long).

\section{IVIC-547. Bahía El Tablazo C-25}

$$
1170 \pm 60
$$

Clayey mud from Bay, E of canal and close to entrance into Gulf of Venezuela $\left(10^{\circ} 56^{\prime} \mathrm{N}\right.$ Lat, $71^{\circ} 33^{\prime} \mathrm{W}$ Long). 


\section{IVIC-547(c). Bahía El Tablazo \\ C-25 carbonates}

$1570 \pm 120$

A.D. 380

Carbonate portion of clayey-mud sample from Bay $\left(10^{\circ} 56^{\prime} \mathrm{N}\right.$ Lat, $71^{\circ} 33^{\prime} \mathrm{W}$ Long). Organic portion also dated.

General Comment: organic-fraction samples from Gulf of Venezuela average 700 B.P.; this agrees with average of samples from the Bay (beyond canal influence) which is 530 B.P. Sedimentation in Canal of Maracaibo is probably due to redeposition of material from sides. Carbonate dates do not agree with organic fractions which should be more reliable of the two (Tamers, 1969b).

\section{Tierra Pipe series}

Soil organic matter accumulation on top of developing layer of clayey earth evolving mainly from mica. Rootlets and other plant debris are abundant. Brown earth of A-C horizon type in Altos de Pipe, State of Miranda, Venezuela ( $10^{\circ} 23^{\prime} \mathrm{N}$ Lat, $66^{\circ} 58^{\prime} \mathrm{W}$ Long), alt ca. $1400 \mathrm{~m}$. Soil mixed thoroughly with water and passed through sieve to remove rootlets. Acid treatment eliminated carbonates; dates came from remaining organic material. Coll. 1969 and subm. by members of Radiocarbon Lab., I.V.I.C.

\section{IVIC-652. Tierra Pipe, 0.15 to $0.30 \mathrm{~m}$}

$2230 \pm 60$

Light brown soil with abundant rootlets. $0.9 \%$ non-carbonate, nonrootlet carbon content.

\section{IVIC-653. Tierra Pipe, 0.30 to $0.45 \mathrm{~m}$}

$4220 \pm 90$

Soil, lighter brown than that of IVIC $652.70 .7 \%$ non-carbonat non-rootlet carbon content.

\section{IVIC-654. Tierra Pipe, 0.45 to $0.60 \mathrm{~m}$}

$5720 \pm 80$

Reddish soil with few carbon content.

General Comment: date sequence agrees with stratigraphy; however, ages are greater than expected since samples were taken from a pit on the side of a steep hill. We had thought erosion here must be considerable, with new surfaces constantly appearing.

Bullbrook, J. A., 1953, On the excavation of a shell mound at Palo Seco, Trinidad, B.W.I.: Yale Univ. Pub. Anthropol., no. 50.

Callow, W. J., Baker, M. J., and Pritchard, D. H., 1964, National Physical Laboratory radiocarbon measurements II: Radiocarbon, v. 6, p. 25-30.

Cruxent, J. M., 1967, El paleo-indio en 'Taima-taima, estado Falcón, Venezuela: Acta Cient. Venezolana, supp. 3, p. 3-17.

Cruxent, J. M. and Rouse, Irving, 1969, Early man in the West Indies: Scientific American, v. 221, p. $42-52$

Pietig, F. and Scharpenseel, H. W., 1966, Altersbestimmung mit dem FlüssigkeitsSzintillations-Spektrometer, Ein neuer Katalysator zur Benzolsynthese: Atompraxis, v. 12 , p. $95-97$. 

Rouse, Irving and Cruxent, J. M., 1963, Venezuelan Archaeology: New Haven, Yale
Univ. Press.

Scharpenseel, H. W. and Pietig, F., 1969, Altersbestimmung von Böden durch die Radiokohlenstoffdatierungsmethode III, Böden mit $\mathbf{B}_{\mathrm{t}}$-Horizont und fossile Schwarzerden: Zeitschr. Pflanzenernährung und Bodenkunde, v. 122, p. 145-152.

Tamers, M. A., 1966, Instituto Venezolano de Investigaciones Científicas natural radiocarbon measurements II: Radiocarbon, v. 8, p. 204-212. carbon measurements III: Radiocarbon, v. 9, p. 237-245.

$1967 \mathrm{~b}$, Surface water infiltration and ground water movement in arid zones of Venezuela, in: Isotopes in Hydrology, I.A.E.A., Vicnna, p. 339-353.

carbon 1969a, Instituto Venezolano de Investigaciones Científicas natural radiocarbon measurements IV: Radiocarbon, v. 11, p. 396-422.

1969b, Radiocarbon datin! of recent events: Atompraxis, v. 15, p. 271-276.

1969c, Teneurs en radiocarbone des sédiments superficiels dans la Baie d'El Tablazo, Vénézuéla: Comptes rendus, Acad. Sci. (Paris), v. 269D, p. 1378-1381.

Vogel, J. C. and Waterbolk, H. T., 1967, Groningen radiocarbon dates VII: Radiocarbon, v. 9, p. 107-155.

Wagner, Erika, 1967, The prehistory and ethnohistory of the Carache area in western Venezuela: Yale Univ. Pub. Anthropol., no. 71.

Zucchi, Alberta, 1965, Informe preliminar de las excavaciones del yacimiento La Betania, estado Barinas, Venezuela: Indigenista Venezolano Bol., v. 10, p. 155-168. 